\title{
From Mussels Stand to Becoming a Doctor: A Discussion on the Importance of Education in the Vertical Transition Between Social Strata in Terms of Career Choices and Sources of Vocational Awareness in Children with Low Socioeconomic Level
}

\author{
Emel TÜZEL İşER $\dot{I}^{1}$ \\ ${ }^{1}$ Faculty of Education, Tokat Gaziosmanpaşa University, Tokat, Turkey \\ Correspondence: Emel TÜZEL İŞERİ, Department of Educational Sciences, Faculty of Education, Tokat \\ Gaziosmanpaşa University, Tokat, Turkey.
}

Received: June 12, 2019

Accepted: July 28, 2019 Online Published: October 25, 2019

doi:10.5539/ies.v12n11p94

URL: https://doi.org/10.5539/ies.v12n11p94

\begin{abstract}
This study aims to discuss the importance of education in vertical transition between social strata in the context of career choices and vocational awareness sources in children with low socioeconomic level. The study used a phenomenological design within a qualitative research approach framework. The study group consisted of 55 fourth-grade students enrolled in a primary school in a low socioeconomic area of Izmir province in Turkey. Findings of the research laid out that the students mostly wanted to be a doctor, their positive attitudes towards the profession and their desire to be beneficial to the society gained importance in their career choices, taking the example of people who they encountered in real life and who they watched on TV affected their career choices, and that there were participant views indicating that a thorough presentation of careers was not conducted even though a number of professions were mentioned in the lesson. The findings were discussed in terms of carrying out vocational guidance more carefully for participants consisting of children with low socioeconomic level who have parents with low education level so that its disadvantages can be eliminated.
\end{abstract}

Keywords: career choice, low socioeconomic level, social strata, vertical mobility, primary school students

\section{Introduction}

Career, which is defined as profession that is based on systematic knowledge and skills gained through certain education, carried out to produce useful goods for people, provide service, and make money in return, and is based on predetermined rules (TDK, 2018), is one of the most important individual variables which assign the individual a certain status and roles in society and accordingly ascertain the place of the individual in social life. Career choice can be said to involve a process where the individual also chooses a lifestyle and living environment rather than fulfilling a certain set of tasks reflecting their motivation, knowledge, personality, and skills (Holland, 1959). Having a recognized profession in society allows a person to have economic, social, political, and legal privileges and to earn esteem (Arslan, 2001). Accordingly, given the fact that the career that the individual chooses directly affects their life standards, possibilities, and cultural and social life, career choice, indeed, can be said to be the process whereby the individual determines the type of life they will live.

In addition to individual factors such as beliefs, values, interests, skills, personality traits that determine the profession that the individual chooses (Savickas, 1991), it is possible to mention the effect of external factors such as obtaining a financial benefit and achieving social status and respect as well (Downey, McGaughey, \& Roach, 2011). In other words, career choice arrives at the end of a complex decision-making process consisting of the individual's internal factors and the external factors surrounding the individual and the combination of both internal and external factors.

Blau et al. (1956) emphasize the importance of social structure that affects individual and social factors in the career choice of an individual and state that social structure consists of factors such as class order of the society, cultural values, the structure of the population (age, gender, education, etc.), and the level of economic and technological development of the society. The growing importance of education in the process of social mobility is closely associated with the transition from the stage of offering privileges specific to a particular stratum to 
spreading throughout all segments of society. The spread of educational opportunities, which take on an important function in the process of transition from low socioeconomic classes to high socioeconomic classes, has gained momentum with the introduction of modern industrial societies (Alix, 1995 cited in Güzel, 2007). According to the theory of industrial society, industrialization brings about building, developing, and reorganizing educational institutions to meet the labor force industrial institutions need, which, in turn, increases educational opportunities. Accordingly, educational institutions become open to all individuals from different social classes and individuals in different social classes can benefit from educational institutions. As a result, individuals can achieve vertical social mobility through education and promote to professional and managerial positions that require education/knowledge through education (Şengönül, 2008). In addition, the tradition of inheriting professions from father to son can be said to decrease to a great extent. Today, all high-status professions are granted to individuals in all social classes, at least theoretically, according to their predisposition, skills, and energy. Recognition of equal opportunity for everyone in the rise in social structure has been accepted by the constitutions of all countries; nevertheless, many challenges still prevail (Ergün, 1997). For example, the "Social Status Theory" developed by Beoudon in 1974, lays out that education and career choice came up according to a cost-benefit analysis regarding individuals in different social classes, vocational-technical education is not preferred by high socioeconomic social classes because choosing it meant a kind of degradation, and that children prefer a level of education and career similar to those of their parents even if their skills fit a higher level. In addition, it is also emphasized that the same condition would require a more material sacrifice for a worker's child and that careers with high esteem and social status would be less preferred by these children because the family would tend to press less for this choice (Beoudon, 1974 cited in Doğan, 2004). On the other hand, although it is an undeniable fact that children born to rich, educated, and intellectual families are at a better starting point in the life race compared to children born to poor and uneducated families (Eke, 1987) as conceptualized by Weber using the "life chances" concept, social systems endeavor to establish an order to ensure the social rise of individuals according to their skills and achievements. Bureaucratic systems and hierarchical ascending orders can be given as an example of the case (Ergun, 1997).

The way individuals interact with their environment and individual and environmental characteristics affect their career choices (Holland, 1997; Spokane \& Cruza-Guet, 2005). However, awareness of the reasoning processes that children employ in making career choices helps to sustain career education and research for children and young people (Howard \& Walsh, 2011). The vocational development process in individuals is manifested in five stages including awakening and awareness, discovering and investigating careers, decision-making, preparation, and employment (Isaacson, 1986 cited in Yeşilyaprak, 2004). In the process of choosing a career, the ages between 5-12 comprising preschool and primary school period of the child can be defined as "awakening and awareness" stage. Children in this age range grasp the existence of occupations and begin to, though a little, gain awareness about the interests and skills that these occupations require. In this period, although the child's source of information about the occupations is family and school, the awareness of the child is also limited to their curiosity (Isaacson, 1986 cited in Yeşilyaprak, 2004). On the other hand, this limitation can be said to be overcome by the family and school by familiarizing the child with different professions, and by the child itself by observing different professions and having an idea about the profession. Gokuladas (2010) states that students' perceptions of a profession are effective in the decision-making process during their first career choice and that perceptions of the profession play an important role in their life because it will affect the student's future decisions. That students have knowledge of careers, they learn what they do not know about careers that they are interested in and choose, and that they find an opportunity to choose among a wider range of choices by getting familiar with careers that they have no idea of or have misconceptions or incomplete information about is of great significance in terms of changing their stereotyped prejudgments and false beliefs towards various professions and attain the idea that all professions that are beneficial to society and allow self-realization are worth showing respect (Kuzgun, 2000). Howard (1959) and Spokane, Luchetta, and Richwine (2002) state that individuals with more knowledge about vocational settings make more appropriate career choices, and in this context, they emphasize that parents and teachers should inform the individual and that they should concentrate on the contribution of the child to career choice (Howard, 1959 cited in Spokane, Luchetta, \& Richwine, 2002).

Alpman (2009) states that education is seen by parents as a means of not only gaining economic capital but also of moving to an upper class or of extending out of the present social boundaries, and that parents of almost all economic levels have a perception that is associated with both economic and social and class-based positions by strongly agreeing on the proposition that "I am sending my child to school to ensure a better position than mine". Accordingly, vocational guidance for children who are disadvantaged in terms of socio-cultural and economic aspects is of great importance in order for them to have better living conditions in the future via their professional choices. According to Seligman (1980), the professional development of the individual is considered as a process 
that includes the physical, mental, and emotional development that lasts for a lifetime and also involves the career selection process. The concept of professional development is directly related to how the idea of profession as a process develops in children and young people (Kepçeoglu, 2004). On the other hand, while there is a limited number of studies on primary school period (Selanik-Ay \& Emeksever, 2016; Özdemir-Yaylac1, 2007) when the idea of professions first form, various studies investigating factors that affect students' career choices have been observed to focus on students of middle school (Akdeniz, 2009; Gelişli, Kazykhankyzy, \& Shauyenova, 2018; Özen, 2010), high school (Altıntop, 2015; Bacanl1, 2012; Eraslan-Çapan \& Korkut-Owen, 2017; Gezer, 2010; Tanhan \& Yılmaz, 2017; Turan \& Kayıkçı, 2019; Ulaş et al., 2017), and university level (Arslan, Güriper, \& İnce, 2017; Atabay, Karakaş, Yıldırım-Kutbay, \& Alamur, 2018; Atli \& Kaya, 2017; Ayas, Deniz, \& Kağan, 2010; Eren, 2012; Köksal, 2016; Pekkaya \& Çolak, 2013).

Despite the views and practices that career education should begin in secondary education, today the idea that career education should be started in primary education is getting more common. On the other hand, although the practices on career choice are conducted on education and human base, they are observed to be handled mostly within the scope of guidance and psychological counseling, to be deprived of enough interdisciplinary research and practice, and to lack integrity, policy, vision, and resources at the national level (Özdemir-Yaylac1, 2007). While there are a few studies investigating career choices at primary school level, there are no studies examining career choice among disadvantaged groups with low socioeconomic level. This study is expected to make contributions to literature in these areas.

\subsection{The Aim of the Study}

As can be seen, having knowledge of professions, socio-economic and cultural factors, as well as individual interests and skills, have a significant impact on individuals' career choices. For this reason, it is important that schools provide informative professional guidance for students who are socio-culturally and economically disadvantaged from an early age. This study aimed to determine the career choices of primary school students with low socioeconomic level who belong to the disadvantaged groups of society, the reasons for choosing a certain career, and the factors allowing them to have awareness of this career, and to offer some possibilities to these children for gaining vocational awareness at an early age in line with the results of the study. For this purpose, the following questions were investigated: Primary school students with lower socioeconomic level;

1) What do they want to be when they grow up?

2) What were their reasons for wanting to do the job that they chose?

3) How did they come up with the choice of this career?

4) Do they know anyone of the profession that they chose?

5) Have they learned the characteristics of the career that they chose at school?

\section{Method}

\subsection{Study Design}

The study used a phenomenology method within a qualitative research framework (Neuman, 2006) whose data consisted of documents, observations, or transcribed images and talks. Phenomenological studies aim to reveal individuals' experiences, perceptions, and the meanings individuals attribute to them relating to a phenomenon (Yıldırım \& Şimşek, 2011). The study aimed to obtain in-depth information about the topic of the research, and the questionnaire forms that were prepared by the researcher and contained open-ended questions were filled out by the participants.

\subsection{The Study Group}

The study group of the research consisted of 55 fourth-grade students enrolled in a primary school in a low socioeconomic area of the central county of Izmir province. The data was collected between 26th and 28th March in 2018.

Participants were determined using purposive sampling technique. In purposive sampling, the researcher decides on who will be included in the sample and puts the ones that are most suitable for the research purpose into the sample (Balc1, 2007). In this context, during the selection of the sample of the present study, a school with a low socioeconomic level that suited the purpose of the research was determined, and 3 different classroom teachers working in the school were asked to determine the students with the lowest economic status and to inform the researcher about them. The students who were determined according to the opinions of the teachers were included in the study group. Demographic variables of the students in the study group are given in Table 1. 
Table 1. Demographic variables of participating students $(\mathrm{N}=55)$

\begin{tabular}{|c|c|c|}
\hline \multicolumn{2}{|c|}{ Demographic Variables } & $\mathrm{f}$ \\
\hline \multirow{2}{*}{ Gender } & Girl & 27 \\
\hline & Boy & 28 \\
\hline \multirow{3}{*}{ Age } & 9 & 15 \\
\hline & 10 & 37 \\
\hline & 11 & 3 \\
\hline \multirow{2}{*}{ Mother's Job } & Housewife & 50 \\
\hline & Worker & 5 \\
\hline \multirow{4}{*}{ Father's Job } & Street vendor (mussel seller: 13) & 37 \\
\hline & Worker & 10 \\
\hline & Tailor & 5 \\
\hline & Unemployed & 3 \\
\hline \multirow{5}{*}{ Mothers' graduation } & No formal education & 25 \\
\hline & Elementary school & 24 \\
\hline & Middle school & 3 \\
\hline & High school & 3 \\
\hline & University & - \\
\hline \multirow{5}{*}{ Fathers' graduation } & No formal education & 14 \\
\hline & Elementary school & 33 \\
\hline & Middle school & 3 \\
\hline & High school & 5 \\
\hline & University & - \\
\hline
\end{tabular}

As is seen in Table 1, 28 of the participants were male, 37 were 10 years old, mothers of 50 were housewives, fathers of 37 were street vendors (13 were mussel sellers), mothers of 25 had never gone to school, and fathers of 33 were primary school graduates. There were no participants whose parents were university graduates.

\subsection{The Data Collection Tool and Data Collection}

Within the scope of the research, the questionnaire form including open-ended questions created by the researcher was administered to the students. The questionnaire was created by examining the relevant literature and then, in order to evaluate content validity, the form was submitted to the opinions of experts from fields including educational management, primary school teaching, psychological counseling and guidance, and measurement and evaluation. The form, which was arranged in accordance with the suggestions, was re-arranged in accordance with the views of four different classroom teachers in terms of comprehensibility and conformity with the level of the participants. Accordingly, the language of the form was simplified and its final form was obtained.

The first part of the data collection tool gathered information about personal details consisting of students' gender, age, mother's job, father's job, mother's education, and father's education variables and the second part involved open-ended questions of the study such as "1) What do they want to be when they grow up?; 2) What were their reasons for wanting to do the job that they chose?; 3) How did they come up with the choice of this career?; 4). Do they know anyone of the profession that they chose?; and 5) Have they learned the characteristics of the career that they chose at school?"

The data collection tools were administered to the students in three different classes under the supervision of their teachers. Questions that were not understood by the students were explained by the teachers and the researcher, and thus the forms were filled out completely.

\subsection{Data Analysis}

Content analysis technique was employed for analyzing the data obtained from the participants. In qualitative research, the researcher analyzes the data by categorizing them on the basis of themes, concepts, or similar characteristics (Neuman, 2006). When the content analysis is carried out, similar data are put together under certain concepts and themes, and the research findings are organized and interpreted in a way through which readers can understand them (Creswell, 2012). Concepts and themes that are not discovered with a descriptive approach are discovered as a result of this analysis (Yıldırım \& Şimşek, 2011).

First, the data obtained were read altogether, the codes related to the expressions were formed, and the codes that 
were similar and could be handled together were combined to determine the themes.

In order to achieve the internal validity of the study, the themes and codes obtained were submitted to the opinion of two experts including one expert from the educational management field and another from the primary school teaching field. As a result of the evaluations, themes and codes were given their final forms.

\section{Results}

1) The first sub-problem of the study had been determined as "What do primary school students with low socioeconomic level want to be when they grow up?" Table 2 shows the results of the content analysis conducted to examine the answers to this question.

Table 2. Jobs that the participants chose $(\mathrm{N}=55)$

\begin{tabular}{ll}
\hline Jobs & $\mathrm{f}$ \\
\hline Doctor & 15 \\
Police officer & 8 \\
Teacher & 6 \\
Pilot & 4 \\
Architect & 2 \\
Lawyer & 2 \\
Designer - Stylist & 2 \\
İmam (A Muslim Religious Leader) & 2 \\
Gendarmerie & 2 \\
Cook, firefighter, veterinarian, painter, car mechanic, astronaut, mathematician, pet shop owner, engineer, grocer, & 1 (each was encountered \\
mechanic, construction worker & once) \\
\hline
\end{tabular}

As is seen in Table 2, the participants mostly wanted to be a doctor ( $f=15)$. This was followed by police officer ( $f$ $=8$ ), teacher $(f=6)$, and pilot $(f=4)$, respectively. While there were 2 participants in each of the architect, lawyer, designer-stylist, imam and gendarmerie job categories, each of the other jobs such as cook, firefighter, veterinarian, painter, car mechanic, astronaut, mathematician, pet shop owner, engineer, grocer, mechanic, and construction worker was chosen by one student. The participants mentioned nine different occupations that were repeated more than once. In addition, considering the jobs mentioned only once, the students were found to mention 21 different occupations in total as their future professions.

2) The second sub-problem of the study had been determined as "What were the reasons of primary school students with low socioeconomic level for wanting to do the job that they chose?" The results of the content analysis conducted to examine the answers to this question are given in Table 3.

Table 3. The Reasons of the participants for choosing the job $(\mathrm{N}=55)$

\begin{tabular}{|c|c|}
\hline Themes & Codes \\
\hline \multirow{2}{*}{ Having a positive attitude $(\mathrm{f}=23$ ) } & I love it $(\mathrm{f}=18)$ \\
\hline & A nice job $(f=5)$ \\
\hline \multirow{2}{*}{ Social benefits $(\mathrm{f}=20)$} & Saving - helping people $(\mathrm{f}=18)$ \\
\hline & Saving my country $(\mathrm{f}=2)$ \\
\hline \multirow{3}{*}{ Having an interest -curiosity ( $\mathrm{f}=4$ ) } & I am interested in this job $(\mathrm{f}=2)$ \\
\hline & I want to fly $(\mathrm{f}=1)$ \\
\hline & I'm curious about the space $(\mathrm{f}=1)$ \\
\hline \multirow{2}{*}{ Individual benefits ( $\mathrm{f}=4$ ) } & Earns a lot of money $(\mathrm{f}=3)$ \\
\hline & We have a case at the court $(\mathrm{f}=1)$ \\
\hline Having knowledge of the job $(\mathrm{f}=2)$ & I have knowledge about the job $(\mathrm{f}=2)$ \\
\hline Having necessary skills $(\mathrm{f}=1)$ & I have skills $(\mathrm{f}=1)$ \\
\hline No specific reasons $(\mathrm{f}=4)$ & I have no idea $(\mathrm{f}=4)$ \\
\hline
\end{tabular}

Table 3 indicates that the participants used 58 statements about the reasons for doing the profession of their choice. These statements were gathered under 7 different themes including "having a positive attitude, social benefits, 
having an interest-curiosity, individual benefits, having knowledge of the job, having necessary skills, and no specific reasons" and assigned 13 different codes. According to the findings, the majority of the participants were found to state their reasons for choosing the job in more general terms such as "I love it", and to prefer achieving social benefits rather than choosing the profession based on their awareness of their interests, knowledge, and skills or getting individual benefits.

3) The third sub-problem of the study had been determined as "How did the primary school students with low socioeconomic level come up with the choice of this job?" The results of the content analysis regarding the examination of the answers to this question are given in Table 4.

Table 4. How did the participants come up with the choice of this job? $(\mathrm{N}=55)$

\begin{tabular}{ll}
\hline Themes & Codes \\
\hline \multirow{3}{*}{ Taking the example of someone $(\mathrm{f}=28)$} & $\begin{array}{l}\text { I saw-watched it in real life }(\mathrm{f}=14) \\
\text { I watched it on TV }(\mathrm{f}=8) \\
\\
\text { There is someone of the same job in the family }(\mathrm{f}=6)\end{array}$ \\
\hline Having positive attitudes $(\mathrm{f}=15)$ & I love it $(\mathrm{f}=15)$ \\
\hline Family guidance $(\mathrm{f}=4)$ & My elder brother told me about it $(\mathrm{f}=2)$ \\
& My mom told me about it $(\mathrm{f}=1)$ \\
\hline Social benefits $(\mathrm{f}=2)$ & I thought I would be beneficial for people $(\mathrm{f}=2)$ \\
\hline \multirow{2}{*}{ Learning at school $(\mathrm{f}=2)$} & I learned it from the science textbook $(\mathrm{f}=1)$ \\
\hline \multirow{2}{*}{ Unclear $(\mathrm{f}=10)$} & My teacher supported me about it $(\mathrm{f}=1)$ \\
\hline
\end{tabular}

As can be seen in Table 4, participants responded to the question about how they came up with the idea of this job with a total of 57 statements. The statements were grouped under 6 different themes such as "taking the example of someone, having positive attitudes, family guidance, social benefits, learning at school, and unclear" and 12 different codes were determined.

The findings indicated that the participants made their career choices mostly by "taking the example of someone". This choice was mostly based on "seeing-watching someone do the profession in real life". This was followed by "watching someone who does the profession on TV" and "the presence of a relative who does the profession", respectively. It is noteworthy that the number of participants referring to family guidance and learning about it at school was quite low.

4) The fourth sub-problem of the study had been determined as "Do the primary school students with low socioeconomic level know anyone of the profession that they chose?" The results of the content analysis regarding the examination of the answers to this question are given in Table 5.

Table 5. Do they know anyone of the same job? $(\mathrm{N}=55)$

\begin{tabular}{ll}
\hline Variables & $\mathrm{f}$ \\
\hline Yes & 21 \\
No & 34 \\
\hline
\end{tabular}

Table 5 shows that approximately three-fifths of the participants did not have any acquaintances who do the job that they chose. According to this, in the career choice of the participants, people who they encountered and people who take the example of can be said to be more important than the people they know.

5) The fifth sub-problem of the study had been determined as "Did the primary school students with low socioeconomic level learn the features of the job that they chose at school?" The results of the content analysis regarding the examination of the answers to this question are given in Table 6. 
Table 6. Was job introduced/learned at school? What course was it? $(\mathrm{N}=55)$

\begin{tabular}{lll}
\hline & Lessons & $\mathrm{f}$ \\
\hline & Life sciences & 21 \\
& Traffic & 10 \\
The job was introduced in the lesson (f=51) & Turkish & 7 \\
& Science & 5 \\
& Art & 3 \\
& Counseling & 2 \\
The job was introduced in the lesson, but we did not learn its features. $(\mathrm{f}=12)$ & & 2 \\
\hline
\end{tabular}

As is seen in Table 6, almost all of the students stated that they were introduced to the jobs that they chose in life sciences, traffic, Turkish, science, art, counseling, religion, and mathematics courses, whereas about one-fifth of the participants stated that the jobs they chose were introduced in the lessons, but students reported that their properties were not taught. Accordingly, although various professions were included in the course contents, there were deficiencies in making direct vocational presentations in detail and in a memorable manner when the participant statements that included detailed evaluation were taken into consideration.

\section{Discussion}

The participants of this study consisted of primary school students from low socioeconomic families. Nearly all of their mothers were housewives and all of their fathers had low-status jobs such as street vendor, salesperson, worker, or they were unemployed. Majority of the parents had low education or were uneducated. The study revealed that the participants mostly wanted to be a doctor. According to Turkey Socio-Economic Status Index Project conducted by Sunar et al. (2015), the occupation that has the highest prestige in Turkey was determined as medical doctor, whereas street vendor was identified to be one of the first three professions with the lowest prestige. In the same survey, the reputation score of being a housewife, not having a career, or being unemployed was calculated as zero. When considered in this context, it is noteworthy that children, almost all of whose mothers were housewife, and the majority of whose fathers were unemployed or had low-status jobs such as street vendor, wanted to be a medical doctor. In a study conducted by Selanik-Ay and Emeksever (2016) which aimed to determine the vocational perceptions of primary school children with low, middle, and high socioeconomic level by analyzing the stories that were written by the students, the most mentioned profession in students' stories was found to be the teaching profession. This was followed by the profession of a medical doctor. Although the results of both studies seem similar, the results of the present study, which was carried out exclusively on students with low socioeconomic status, showed that the participants showed more interest in the profession of doctor, which has a higher status, than the profession of teacher, which was preferred by low, middle, and upper socioeconomic level students.

Kuzgun (2000) emphasizes that children may make up for their weaknesses by identifying themselves with strong adults, and therefore, they often imitate the actions and activities of an adult in their close circles or a fairy tale or movie hero who they admire. They believe they can identify themselves with adults in this way, and as a result, they can state their occupations as their future profession (Selanik-Ay \& Emeksever, 2016). The sample of this study consisted of children majority of whose fathers were street vendors and one-third of these street vendors were mussel sellers. It is also noteworthy that the second most preferred profession of the children of these fathers was police officer, given the fact that there is usually a "cat and mouse" game, fight, and tension between these fathers and the police or municipal police, which is also reflected in the media, because they do not have a license for selling mussels.

The study found that the majority of the participants with parents who have low level of education preferred occupations such as doctor, police officer, teacher, pilot, architect, or lawyer, which requires undergraduate education. Although it is known that fathers with higher education level are known to be more conscious about guiding their children to professions with high prestige compared to fathers with low-level education (Güzel, 2007), raising awareness in parents with low socioeconomic levels and low-level of education about the importance of education in the career choice of their children and vertical social mobility is of great significance in terms of the continuance of their children's education and supporting them.

According to Ginzberg et al. (1951), children make clear and obvious occupational preferences at a very young 
age. However, the pleasure principle plays an important role in these choices, meaning that children say they want to do the occupations they like. Children do an activity only because they like it, and they tend to do it because of the affinity they feel for the essence of the activity (Ayas, Deniz, \& Kağan, 2010). According to the findings of the study, the participants mostly defined their reasons for choosing a certain profession in more general terms such as "I love this job", as emphasized by Ginzberg et al. (1951). In addition, the participants were observed to choose the profession based on their interests, knowledge, and skills, or for reasons of social benefit rather than personal benefits. In other words, the results of the study showed that taking the example of someone or positive perceptions of a job gained importance in the career choices of the participants. However, the number of participants stating that they chose the profession through vocational guidance was quite low. Approximately one-fifth of the participants stated that they had not received any information at school about the job that they chose and that they had not encountered any information about these professions during the courses. Nevertheless, the career journey of individuals starts with the choice of a profession and continues along the vocational education process. In order for the individual to make the right and healthy career choices, which will profoundly affect their future life, it is highly important that they have accurate perception and knowledge about the profession (Bozkurt \& Soylu, 2018).

Another finding showed that the participants made most of their career choices through "taking the example of someone". This method of choosing a career was followed by "seeing-watching someone of this profession in real life." The next methods were "watching someone do the profession" and "having a relative of the same profession". It is remarkable that the number of participants referring to "family guidance" and "hearing about the job at school" was quite low. On the other hand, about three-fifths of the participants stated that they did not have any acquaintances that do the job they chose. Considering the high-status professions chosen by these children with low socioeconomic level, it can be said that the socioeconomic and cultural environment in which they live was proven to be inadequate and disadvantageous in the process of taking the example of someone for choosing a job. On the other hand, given the fact that these children were far from a professional orientation in the school as well as their familial disadvantages, they can be said to have professional awareness through the people they encounter, see or come across in their daily lives or on TV. Özen (2010), who conducted research on $7^{\text {th }}$-grade students, also found that students with similar low socioeconomic status were more likely to be under the influence of television programs in terms of knowing and choosing professions compared to students with middle and upper socioeconomic levels and that the content of TV programs that children watch had a guiding effect on them.

When all of the findings of the participating children in the study were evaluated together, it can be stated that Turkish National Education system is far from achieving its basic goals of "guiding students to a profession in accordance with their interests, talents, and skills", which is stated in the National Education Basic Law no 1739, and also, the system cannot adequately apply the "orientation principle", which is one of the 14 basic principles cited in the same Law (Milli Eğitim Temel Kanunu, 1973). Demir (2004), who investigated the opinions of primary school teachers about improving students' interests and abilities, found that teachers did not invite relevant source persons to their classes in order to develop the interests and abilities of their students in and out of their courses and that they did not take the students to business areas such as factories or workshops. However, these activities can be said to be highly important when we think that presenting professions to children at an early age, inviting people of different professions to school, and providing information about professions to families and children have a considerable effect on the life choices of children.

When the occupations chosen by the participants were examined, all of them were found to make choices for occupational groups that are frequently known by society such as doctor, police officer, and teacher. According to the "Future Jobs Report" of World Economic Forum (WEF) released in 2018, most of the occupations currently underway, including mostly blue-and-white collar jobs, will become unnecessary (redundant) in the future. In this context, while we are educating adults of the future, inform and guide children by defining their future professional skills and needs is of great significance (Tüzel-Işeri, 2018). According to the findings of the study, the occupational groups introduced in the textbooks and course contents were effective in the career choices of the participants. Accordingly, it can be said that instead of stereotyped vocational presentations, different occupation groups that will shape the future should be included in the lessons.

This study aimed to emphasize the importance of education in terms of achieving the vertical mobility of the students with low socioeconomic level and therefore the study was limited to the career choices of the children with low socioeconomic level and the factors affecting these choices. Researchers who want to do research on a similar topic are suggested to increase the sample size and handle the issue from different perspectives by conducting qualitative studies that compare parents with different educational levels, different cultural structures, and students with different socioeconomic levels. Further studies on this topic will provide a source for policymakers, researchers, and educators in eliminating social inequality, ensuring vertical social mobility, and 
supporting disadvantaged children.

\section{Acknowledgments}

This study was presented at 17th International Primary Teacher Education Symposium (IPTES, 2018), Ankara, Turkey.

\section{References}

Akdeniz, S. (2009). Ergenlerin meslek karart verme yetkinlik algılarının, algllanan ana-baba tutumu ve bazı özlük nitelikleri açısından incelenmesi (Unpublished masters thesis). Selçuk Üniversitesi, Sosyal Bilimler Enstitüsü, Konya.

Alpman, P. S. (2009). Toplumsal sinıflar ve eğitim (Unpublished masters thesis). Selçuk Üniversitesi Sosyal Bilimler Enstitüsü, Konya.

Altıntop, M. (2015). Ortaöğretim ögrencilerinde mesleki yönelim ve girişimcilik (Unpublished masters thesis). İstanbul Gelişim Üniversitesi, Sosyal Bilimler Enstitüsü, İstanbul.

Arslan, E., Güripek, E., \& İnce, C. (2017). Kişilik ve meslek seçimi ilişkisi: Turizm öğrencileri üzerine bir araştırma. Kesit Akademi Dergisi, 3(11), 200-217. https://doi.org/10.18020/kesit.1297

Arslan, M. (2001). İs ve meslek ahlakr. Ankara: Nobel Yayınevi.

Atabay, I., Karakas, F., Kutbay-Yıldırım, A., \& Alamur, B. (2018). A field research on factors affecting banking job selection. PressAcademia Procedia $\quad$ (PAP), $\quad 7, \quad$ 186-190. https://doi.org/10.17261/Pressacademia.2018.878

Atli, A., \& Kaya, M. (2017). Üniversite öğrencilerinin mesleki kişilik tipleri. Bingöl Üniversitesi Sosyal Bilimler Enstitüsü Dergisi, 7(14), 331-342. https://doi.org/10.29029/busbed.322778

Ayas, T., Deniz, M., \& Kağan, M. (2010). Ginzberg ve arkadaşlarının gelişim kuramına dayalı örnek bir mesleki grup rehberliği çalışması. Uluslararası İnsan Bilimleri Dergisi, 7(2), 1096-1117.

Bacanl1, F. (2012). Kariyer karar verme güçlükleri ve meslek seçimine ilişkin akılcı olmayan inançların ilişkisi. Türk Psikolojik Danışma ve Rehberlik Dergisi, 4(37), 86-95.

Balcı, A. (2007). Sosyal bilimlerde araştırma: Yöntem, teknik ve ilkeler. (6. Baskı). Ankara: Pegem A Yayıncılık.

Blau, P. M.,Gustad, J. W., Jessor R., Parnes, H. S., \& Wilcock, R. C. (1956). Occupational choice: A conceptual framework. Industrial and Labor Relations Review, 9(4), 531-543. https://doi.org/10.1177/001979395600900401

Bozkurt, Y., \& Soylu, A. (2018). İletişim eğitimi alan ön lisans ve lisans öğrencilerinin reklamcılık mesleğine yönelik algı karşılaştırması: Pamukkale Üniversitesi örneği. Anemon Muş Alparslan Üniversitesi Sosyal Bilimler Dergisi, 6(ICEESS' 18), 37-45. https://doi.org/10.18506/anemon.452610

Creswell, J. W. (2012). Research design: Qualitative, quantitative, and mixed methods approaches (4th ed.). United States: Pearson Education Limited.

Demir, K. (2004). İlköğretim okulu öğretmenlerinin öğrencilerin ilgi ve yeteneklerinin geliştirmesi ile ilgili düşünceleri. XIII. Ulusal Eğitim Bilimleri Kurultayı, 6-9 Temmuz 2004, İnönü Üniversitesi, Eğitim Fakültesi, Malatya. Retrieved from https://pegem.net/dosyalar/dokuman/78003223.pdf

Doğan, İ. (2004). Sosyoloji: Kavramlar ve Sorunlar (6. Baskı) Ankara: Pegem Yayıncılık.

Downey, J. P., McGaughey, R., \& Roach, D. (2011). Attitudes and influences toward choosing a business major: the case of information systems. Journal of Information Technology Education, 10, 231-251. https://doi.org/10.28945/1502

Eke, B. (1987). Bir sosyal sınıf belirleyicisi olarak meslek faktörü. İstanbul Üniversitesi İktisat Fakültesi Mecmuast, 43, 377-401.

Eraslan-Çapan, B., \& Korkut-Owen, F. (2017). Ortaöğretim öğrencilerinin yönelmeyi düşündükleri eğitim alanları ve kariyer psikolojik danışmanlığı. Elektronik Sosyal Bilimler Dergisi, 16(61), 551-568. https://doi.org/10.17755/esosder.304694

Eren, A. (2012). Öğretmen adaylarının mesleki yönelimi, kariyer geliştirme arzuları ve kariyer seçim memnuniyeti. Kastamonu Eğitim Dergisi, 20(3), 807-826

Ergün, M. (1997). Eğitim sosyolojisi (4. Baskı). Ankara: Ocak Yayınları. Retrieved from http://mustafaergun.com.tr/wordpress/wp-content/uploads/2015/11/egsos.pdf 
Gelişli, Y., Kazykhankyzy, L., \& Shauyenova, M. (2018). İlköğretim sekizinci sınıf öğrencilerinin meslek seçimine etki eden değerler (Mardin ili örneği). İlköğretim Online, 17(4), 2216-2228. https://doi.org/10.17051/ilkonline.2019.507006

Gezer, M. (2010). Kariyer planlamasında meslek seçiminin önemi: Mesleklisesi son sinıf öğrencileri üzerine bir araştırma (Unpublished master thesis). Sakarya Üniversitesi Sosyal Bilimleri Enstitüsü, Sakarya.

Ginzberg, E., Ginsburg, S. W., Axelrad, S., \& Helma, J. L. (1951). Occupational choice. New York: Columbia University Press.

Gokuladas, V. K. (2010). Factors that influence first career choice of undergraduate engineers in software services companies: A south Indian experience. Career Development International, 15(2), 144-165, https://doi.org/10.1108/13620431011040941

Güzel, S. (2007). İşçiler ile çocukları arasındaki meslek farklılaşması. Sosyoloji Konferansları, 35, 131-147.

Holland, J. L. (1959). A personality inventory employing occupational titles. Journal of Applied Psychology, 42, 336-342.

Holland, J. L. (1997). Making vocational choices: A theory of vocational personalities and work environments (3rd ed.). Odessa, FL: Psychological Assessment Resources. https://doi.org/10.1037/h0047330

Howard, K. A. S., \& Walsh, M. E. (2011). Children's conceptions of career choice and attainment: Model development. Journal of Career Development, 38(3), 256-271. https://doi.org/10.1177/0894845310365851

Kepçeoğlu, M. (2004). Psikolojik danışma ve rehberlik. İstanbul: Alkım Yayınevi.

Köksal, K. (2016). Üniversite ve meslek tercihini etkileyen unsurlara yönelik bir alan araştırması. Kara Harp Okulu Dergisi, 26(2), 39-69.

Kuzgun, Y. (2000). Meslek Danışmanlığı: Kuramlar, Uygulamalar. Nobel Yayın Dağıtım, Ankara.

Milli Eğitim Temel Kanunu. (1973). T. C. Resmi Gazete (1739, 14 June 1973). Retrieved from http://www.mevzuat.gov.tr/MevzuatMetin/1.5.1739.pdf

Neuman, W. L. (2006). Toplumsal araştırma yöntemleri: Nitel ve nicel yaklaşımlar - I. Ankara: Yayın Odası.

Özdemir-Yaylacı, G. (2007). İlköğretim düzeyinde kariyer eğitimi danışmanlı̆̆ı. Bilig, 40, 119-140.

Özen, Y. (2010). Televizyon'un ilköğretim 7. sınıf öğrencilerinin meslek seçimiyle ilgili algılarına etkisi. Eğitim ve İnsani Bilimler Dergisi: Teori ve Uygulama, 1(2), 61-80.

Pekkaya, M., \& Çolak, N. (2013). Üniversite öğrencilerinin meslek seçimini etkileyen faktörlerin önem derecelerinin ahp ile belirlenmesi. International Journal of Social Science, 6(2), 797-818.

Savickas, M. L. (1991). The meaning of work and love: Career issues and interventions. Career Development Quarterly, 39, 315-324. https://doi.org/10.1002/j.2161-0045.1991.tb00299.x

Selanik-Ay, T., \& Emeksever, A. (2016). İlkokul öğrencilerinin hikâyelerine dayalı olarak mesleklere ilişkin algılarının incelenmesi. Uluslararası Sosyal Araştırmalar Dergisi, 9(44), 968-983. https://doi.org/10.17719/jisr.20164420167

Seligman, L. (1980). Assessment in developmental career counseling. Cranston: The Carroll Pres.

Splaver, S. (2000). Your personality and your career. NewYork, NY: Julian Messner.

Spokane, A. R., \& Cruza-Guet, M. C. (2005). Holland's theory of vocational personalities in work environments. In S. D. Brown, \& R. W. Lent (Eds.), Career development and counseling: Putting theory and research to work (pp. 24-41). Hoboken, NJ, US: John Wiley \& Sons Inc.

Spokane, A. R., Luchetta, E. J., \& Richwine, M. H. (2002). Holland's theory of personalities in work environments. In D. Brown, \& Associates (Eds.), Career choice and development (4th ed., pp. 373-426). San Francisco:Jossey Bass.

Sunar, L., Kaya, Y., Otrar, M., Nerse, S., Demiral, S., \& Kalpaklığlu, B. (2015). Türkiye'de çalışma yaşamı ve mesleklerin itibarl. Türkiye Sosyo-Ekonomik Statü Endeksi Projesi. Retrieved from https://tyap.net/mediaf/Mesleki_\%C4\%B0tibar_Skorlar\%C4\%B1_(Skora_G\%C3\%B6re_Dizili).pdf

Şengönül, T. (2008). Sosyal sınıf kökeni, eğitimsel kazanım ve dikey sosyal hareketlilik ilişkisi. Hacettepe $\begin{array}{lllll}\text { Universitesi Sosyolojik Araştırmalar Dergisi. } & \text { Retrieved } & \text { from }\end{array}$ http://www.sdergi.hacettepe.edu.tr/makaleler/tsengonul.pdf 
Tanhan, F., \& Yılmaz, Ü. (2017). Öğrencilerin kariyer seçimlerinde aile ve sosyal medyanın etkisinin incelenmesi (Bir odak grup çalışması). Yüzüncü Yıl Üniversitesi Sosyal Bilimler Enstitüsü Dergisi, 1(35), $35-47$.

TDK. (2018). Meslek. Retrieved from http://www.tdk.gov.tr/index.php?option=com_gts\&arama=gts\&guid=TDK. GTS.5ccd6307119483.49012073

Turan, Ü., \& Kayıkçı, K. (2019). Lise son sınıf öğrencilerinin meslek seçiminde okul rehberlik hizmetlerinin rolü. E-Uluslararası Ĕgitim Araştırmaları Dergisi, 10(1), 15-33.

Tüzel-İşeri, E. (2018). Eğitimde nereden geldik? Nereye gidiyoruz? 21. yüzyıl sürerken 22. yüzyıl insanını düşünme zorunluluğu üzerine bir tartışma. In E. Tüzel-İşeri (Eds.), 22. yüzyıda eğitim: Eğitimin geleceği üzerine karma projeksiyonlar. Ankara: Pegem Akademi.

Ulaş, Ö., Demirtaş-Zorbaz, S., Dinçel, E. F., Çiffiliz-Kınay, G., \& Coştur, R. (2017). Özel okulda öğrenim görmekte olan lise öğrencilerinin meslek seçimini etkileyen etmenler. Abant İzzet Baysal Üniversitesi Eğitim Fakültesi Dergisi, 17(1), 441-456. https://doi.org/10.17240/aibuefd.2017.17.28551-304647

WEF. (2018). The future of jobs report. Retrieved from http://www3.weforum.org/docs/WEF_Future_of_Jobs_ 2018.pdf

Yeşilyaprak, B. (2004). Eğitimde rehberlik hizmetleri: Gelişimsel yaklaşım. Ankara: Nobel Yayıncılık.

Yıldırım, A., \& Şimşek, H. (2011). Sosyal bilimlerde nitel araştırma yöntemleri (8. Baskı). Ankara: Seçkin Yayıncilik.

\section{Copyrights}

Copyright for this article is retained by the author(s), with first publication rights granted to the journal.

This is an open-access article distributed under the terms and conditions of the Creative Commons Attribution license (http://creativecommons.org/licenses/by/4.0/). 